\title{
Engineering Design Process: A Review and Bibliometric Analysis
}

\author{
Submitted 14 January 2022 Revised 30 January 2022 Accepted 30 January 2022 \\ Ujang Sudrajat ${ }^{1 *}$, Didit Ardianto $^{2}$, Irvan Permana ${ }^{3}$ \\ ${ }^{1,2,3}$ Science Education Program, School of Postgraduate, Universitas Pakuan, Bogor, Indonesia \\ Corresponding Email: *ujang.072621017@unpak.ac.id
}

\begin{abstract}
Currently, science and technology is developing very quickly, so efforts are needed to balance this acceleration, especially in the world of education. Innovations in learning must always be done to keep pace with the development of science and technology. engineering design process (EDP) is one of the strategies available to implement STEM education, has been utilized by many STEM-related subjects educators as a mean to implement STEM (Hafiz and Ayop 2019). The engineering design process allows students to use mathematics and science inquiry to create and conduct experiments for potential design solutions.. The purpose of this paper is providing an extensive bibliometric literature review on engineering design process'. Articles obtained from the Google Scholar database using Publishing or Perish (PoP) software. There were 762 out of 999 articles found from Google Scholar data base ranging from 2016 to 2021 analyzed in this study. The chosen references were then managed using a referencing manager software namely Mendeley. In this research, VOSviewer software is used to classify and visualize the database that has been managed. Overall, this review provides an appropriate reference point for further research on engineering design process
\end{abstract}

Keyword: Bibliometric analysis, Engineering design, Engineering design process, STEM

\section{INTRODUCTION}

Currently, science and technology is developing very quickly, so efforts are needed to balance this acceleration, especially in the world of education. Innovations in learning must always be done to keep pace with the development of science and technology. In a globalised world, countries are in competition in terms of their national economies, scientific and technological development (Sürmeli et al, 2018). In some cases, they have concerns about losing their economic status and about their performance in international science and mathematics assessments resulting in falling behind the other countries (Sürmeli et al, 2018). Design engineering is one of the new educational strategies. To increase students' interest, their positive attitude and understanding of work in natural sciences and engineering can be done by integrating engineering design into science education (Han and Shim 2019).

The NRC (National Research Council) (2009) state that engineering is a scientific discipline that can solve problems within certain limits, and it is also a collection of knowledge that utilizes concepts from science and mathematics, as well as technological tools. (Zheng et al, 2018). Engineering is an important part of STEM Education (Winarno et al. 2020). In the disciplines of engineering and technology, design is of paramount importance at the center of practice and process (Arık and Topçu 2020).

The definition of ABET (Accreditation Board for Engineering and Technology) states that engineering design is the process of developing a system, component, or process to meet the desired requirements. It can be defined as a (often iterative) decision-making process that applies basic 
science, mathematics, and engineering to optimally allocate resources to achieve set goals (Haik and Shahin 2010). According to Carr et al. (2012), engineering design activities have the potential to develop their own efficiency and also students can understand the engineering design process (Yildiz 2020). Nevertheless, traditional classroom environments usually lack design activities and students are not ready to solve design problems that may occur in real life (Yildiz 2020).

One of the important parts in STEM education is engineering. The Engineering Design Process (EDP) is a new trend in science education reform and many science teachers are poorly informed about the use of EDP in science learning (Winarno et al. 2020). In recent years, engineering design process (EDP) is one of the strategies available to implement STEM education, has been utilized by many STEM-related subjects educators as a mean to implement STEM (Hafiz and Ayop 2019). The Engineering Design Process activity is a potential solution that can students can use in mathematical and scientific investigations to create and conduct experiments (Kelley \& Knowles, 2016; Long et al, 2020). In this paper, a bibliometric analysis of the term engineering design process will be carried out.

For this reason, This paper aims to fill the gap in research by provides a bibliometric analysis of the literature on the topic of process engineering design. Articles obtained from the Google Scholar (GS) database are then analyzed and grouped by distribution and author affiliation. From this analysis we can see which research topics are the subject of many publications and which topics in the engineering design process offer further research opportunities. The method used to analyze is using bibliometric analysis. Articles obtained from the Google Scholar database using Publishing or Perish (PoP) software are then presented using VOSviewer. After that, it was continued with a discussion session and conclusions from the literature study using the bibliometric analysis that had been carried out.

"Publish or Perish" is a software program for retrieving and analyzing academic citations developed by Prof. Anne-Wil Harzing of the University of Melbourne (Canada). To get a raw citations, use GS. Then the data is analyzed and presented in various citation metrics in an easy-touse format. The main principle of this PoP software is to create a list of GS results and export them (Baneyx 2008).

\section{METHOD}

This study collected all data from Google Scholar (GS) database as at 6th November 2021. GS database has been used as it is the "largest single abstract and indexing database ever built" and the largest searchable citation and abstract source for literature searches. Some of the analysis results were taken from collected documents such as access type, year, author name, subject, document type, source title, keywords, affiliation, country, source type and language (Ahmi et al, 2019). 
This paper uses VOSViewer to implement a bibliometric analysis of engineering design process. VOSViewer uses a distance-based network to represent the strength of relationships between nodes such as authors, publications, and keywords. Nodes with strong kinship are close to each other. Several relevant nodes form a cluster and are classified by different colors. Also, the size of each node in the network is positively dependent on the weight. The value of weight can be used to express the number of documents, citations, and so on (Li et al. 2021). The fivestage method is used in this study (Hudha et al. 2020) as in Figure 1.

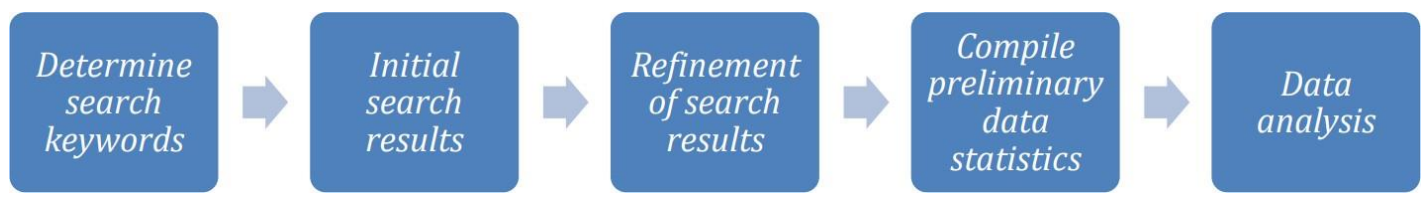

Figure 1. Five-step method bibliometric analysis

\section{Defining search keywords}

The literature search was carried out in November 2021 with the keyword engineering design process. In this study, Google Scholar (GS) was chosen because currently GS is the largest database. Publish or Perish (PoP) is used to search for articles because PoP has proven to be the most effective way to search for articles in the GS database (Baneyx 2008). In the initial search by entering the keyword engineering design process in PoP software.

\section{Initial search results}

This search is devoted only to 'journals' with the keyword 'engineering design process' from 2016-2021 using the Google Scholar database. An initial search found as many as 999 articles. The results are saved in a Research Information System (RIS) format to store all important article information such as paper title, author's name and affiliation, abstract, keywords, and references.

\section{Refinement of the search results}

The articles obtained from the GS database were 999 articles. From this number, the selection is then carried out. Article selection is done by removing proceedings, newspapers, books, book reviews, and book chapters for analysis. In addition, the researchers did not include articles without year of publication, publisher, name of journal, and type of article. Only English articles were entered into the database. The results of the selection obtained 762 articles that match the research topic and the file is saved in the form of a RIS file. The resulting RIS file was used for further data analysis.

\section{Compiling the initial data statistics}

The selected article data is then downloaded and exported into RIS format to include all the necessary information (metadata) for processing in the VOSviewer software. The required information consists of: author, document title, year, number of citations and publisher. 


\section{Data analysis}

PoP software was used for bibliometric analysis in this study and Vosviewer software was used to analyze and visualize the bibliometric network. VOSviewer is used because it can efficiently process large datasets and also provide a variety of interesting visualizations, analyzes, and investigations (Hudha et al. 2020).

\section{RESULTS AND DISCUSSION}

\section{Publications and citation structures}

Next, the data acquired by the PoP software is analyzed by the VOSviewer software to identify the keywords that appear most frequently. The number of keywords that appear most often adjusts to the needs of data collection and analysis carried out. Visualization of bibliometric maps is done using Vosviewer. Three different visualizations in the bibliometric mapping display are generated from this Vosviewer software, namely network visualization, overlay visualization and density visualization.

An initial search using the GS database with the keyword "engineering design process" found 999 articles from 2016 to 2021. In the first result, we obtained about 999 articles with 12478 citations (2495,6/year). From the results of the refinement obtained 762 articles. Information about citations has also changed to 9919 citations (1983.8 citations/year). Comparison of metric data from articles obtained initially and after selection is presented in Table 1.

Table 1. Comparison metrics

\begin{tabular}{lcc}
\hline Metrics data & Initial search & Refinement search \\
\hline Source & 'engineering design process' & 'engineering design process' \\
Publication year & $2016-2021$ & $2016-2021$ \\
Papers & 999 & 762 \\
Citations & 12478 & 9919 \\
Cites/year & 2495.60 & 1983.80 \\
Cites/paper & 12.49 & 13.02 \\
Author/paper & 2.85 & 2.86 \\
h_index & 51 & 47 \\
g_index & 85 & 77 \\
hI_norm & 31 & 28 \\
hI_annual hA- & 6.20 & 5.60 \\
index & 26 & 24 \\
\hline
\end{tabular}

Of the 762 articles that have been selected, the researcher tries to present data on the articles with the most citations. The data are presented in Table 2. 
Tabel 2. Top 10 cited articles

\begin{tabular}{|c|c|c|c|c|c|c|}
\hline No & $\begin{array}{l}\text { Publication } \\
\text { Year }\end{array}$ & Author & Title & Journal & Cites & Publisher \\
\hline 1 & 2016 & $\begin{array}{l}\text { Todd R. } \\
\text { Kelley \& J. } \\
\text { Geoff } \\
\text { Knowles }\end{array}$ & $\begin{array}{l}\text { A conceptual } \\
\text { framework for } \\
\text { integrated } \\
\text { STEM } \\
\text { education }\end{array}$ & $\begin{array}{l}\text { International } \\
\text { Jounal of STEM } \\
\text { Education }\end{array}$ & 966 & Springer \\
\hline 2 & 2017 & $\begin{array}{l}\text { David J. } \\
\text { Shernoff, } \\
\text { Suparna } \\
\text { Sinha, } \\
\text { Denise M. } \\
\text { Bressler \& } \\
\text { Lynda } \\
\text { Ginsburg }\end{array}$ & $\begin{array}{l}\text { Assesing teacher } \\
\text { aducation and } \\
\text { professional } \\
\text { development } \\
\text { needs for the } \\
\text { implementation } \\
\text { of integrated } \\
\text { approaches to } \\
\text { STEM } \\
\text { education }\end{array}$ & $\begin{array}{l}\text { International } \\
\text { Jounal of STEM } \\
\text { Education }\end{array}$ & 203 & Springer \\
\hline 3 & 2017 & $\begin{array}{l}\text { Josef- } \\
\text { Peter } \\
\text { Schöggl } \\
\text { Rupert } \\
\text { J. } \\
\text { Baumga } \\
\text { rtner \& } \\
\text { Dietmar } \\
\text { Hofer }\end{array}$ & $\begin{array}{l}\text { Improving } \\
\text { sustainability } \\
\text { performance in } \\
\text { early phases of } \\
\text { product design: } \\
\text { A checklist for } \\
\text { sustainable } \\
\text { product } \\
\text { development } \\
\text { tested in the } \\
\text { automotive }\end{array}$ & $\begin{array}{l}\text { Journal of } \\
\text { Cleaner } \\
\text { Production }\end{array}$ & 151 & Elsevier \\
\hline 4 & 2016 & $\begin{array}{l}\text { Sevil } \\
\text { Akaygun, } \\
\text { Fatma Aslan- } \\
\text { Tutak }\end{array}$ & $\begin{array}{l}\text { STEM Images } \\
\text { Revealing STEM } \\
\text { Conceptions of } \\
\text { Pre- Service } \\
\text { Chemistry and } \\
\text { Mathematics } \\
\text { Teachers } \\
\text { Effect of }\end{array}$ & $\begin{array}{l}\text { International } \\
\text { Journal of } \\
\text { Education in } \\
\text { Mathematics, } \\
\text { Science and } \\
\text { Technology }\end{array}$ & 148 & Ijemst.org \\
\hline 5 & 2017 & $\begin{array}{l}\text { Kamini Jaipal- } \\
\text { Jamani \& } \\
\text { Charoula } \\
\text { Angeli }\end{array}$ & $\begin{array}{l}\text { Robotics on } \\
\text { Elementary } \\
\text { Preservice } \\
\text { Teachers' Self- } \\
\text { Efficacy, } \\
\text { Science } \\
\text { Learning, and } \\
\text { Computational } \\
\text { Thinking }\end{array}$ & $\begin{array}{l}\text { Journal of Science } \\
\text { Education and } \\
\text { Technology }\end{array}$ & 147 & Springer \\
\hline
\end{tabular}




\begin{tabular}{|c|c|c|c|c|c|c|}
\hline No & $\begin{array}{l}\text { Publication } \\
\text { Year }\end{array}$ & Author & Title & Journal & Cites & Publisher \\
\hline 6 & 2016 & $\begin{array}{l}\text { Edy Hafizan } \\
\text { Mohd Shahali, } \\
\text { Lilia Halim, } \\
\text { Mohamad } \\
\text { Sattar Rasul, } \\
\text { Kamisah } \\
\text { Osman, Mohd } \\
\text { Afendi } \\
\text { Zulkifeli }\end{array}$ & $\begin{array}{l}\text { STEM } \\
\text { Learning } \\
\text { through } \\
\text { Engineering } \\
\text { Design: } \\
\text { Impact on } \\
\text { Middle } \\
\text { Secondary } \\
\text { Students' } \\
\text { Interest } \\
\text { towards } \\
\text { STEM } \\
\text { Learning }\end{array}$ & $\begin{array}{l}\text { EURASIA Journal } \\
\text { of Mathematics } \\
\text { Science and } \\
\text { Technology } \\
\text { Education }\end{array}$ & 145 & $\begin{array}{c}\text { ejmste.co } \\
\mathrm{m}\end{array}$ \\
\hline 7 & 2016 & $\begin{array}{l}\text { Nicola W. } \\
\text { Sochacka, } \\
\text { Kelly. } \\
\text { W. Guyotte, } \\
\text { Joachim } \\
\text { Walther }\end{array}$ & $\begin{array}{l}\text { Together: A } \\
\text { Collaborative } \\
\text { Autoethnographi } \\
\text { c Exploration of } \\
\text { STEAM (STEM } \\
+ \text { the Arts) }\end{array}$ & $\begin{array}{l}\text { Journal of } \\
\text { Engineering } \\
\text { Education }\end{array}$ & 144 & $\begin{array}{l}\text { Wiley } \\
\text { Online } \\
\text { Library }\end{array}$ \\
\hline 8 & 2017 & $\begin{array}{l}\text { Nichole } \\
\text { Pinkard, } \\
\text { Sheena Erete, } \\
\text { Caitlin K. } \\
\text { Martin \& } \\
\text { Maxine } \\
\text { McKinney de } \\
\text { Royston }\end{array}$ & $\begin{array}{l}\text { Education } \\
\text { Digital Youth } \\
\text { Divas: } \\
\text { Exploring } \\
\text { Narrative- } \\
\text { Driven } \\
\text { Curriculum to } \\
\text { Spark } \\
\text { Middle School } \\
\text { Girls' } \\
\text { Interest } \\
\text { in } \\
\text { Computational } \\
\text { Activities }\end{array}$ & $\begin{array}{l}\text { Journal of the } \\
\text { Learning Sciences }\end{array}$ & 143 & $\begin{array}{l}\text { Taylor \& } \\
\text { Francis }\end{array}$ \\
\hline 9 & 2016 & $\begin{array}{l}\text { Natasha A. } \\
\text { Mamaril, Ellen } \\
\text { L. Usher, } \\
\text { Caihong R. Li, } \\
\text { D. Ross } \\
\text { Economy, } \\
\text { Marian S. } \\
\text { Kennedy }\end{array}$ & $\begin{array}{l}\text { Measuring } \\
\text { Undergraduate } \\
\text { Students' } \\
\text { Engineering } \\
\text { Self-Efficacy: } \\
\text { A Validation } \\
\text { Study }\end{array}$ & $\begin{array}{l}\text { Journal of } \\
\text { Engineering } \\
\text { Education }\end{array}$ & 143 & $\begin{array}{l}\text { Wiley } \\
\text { Online } \\
\text { Library }\end{array}$ \\
\hline 10 & 2017 & $\begin{array}{l}\text { Szu-Chun Fan } \\
\cdot \text { Kuang-Chao } \\
\mathrm{Yu}\end{array}$ & $\begin{array}{l}\text { How an } \\
\text { integrative } \\
\text { STEM } \\
\text { curriculum can } \\
\text { benefit students } \\
\text { in engineering } \\
\text { design practices }\end{array}$ & $\begin{array}{l}\text { International } \\
\text { Journal of } \\
\text { Technology and } \\
\text { Design } \\
\text { Education }\end{array}$ & 127 & Springer \\
\hline
\end{tabular}


Table 3 shows the top 10 publishers who publish articles on the topic of Engineering Design Process.

Table 3. Top 10 publishers who publish engineering design process topic

\begin{tabular}{llc}
\hline No & Publisher & Articles \\
\hline 1 & Springer & 107 \\
2 & Taylor \& Francis & 81 \\
3 & asmedigitalcollection.asme.org & 56 \\
4 & ERIC & 47 \\
5 & Wiley Online Library & 29 \\
6 & researchgate.net & 26 \\
7 & Koreascience.or.kr & 25 \\
8 & docs.lib.purdue.edu & 22 \\
9 & Elsevier & 20 \\
10 & Journals.sagepub.com & 17 \\
\hline
\end{tabular}

Journals that have relevant articles are presented in Table 4.

Table 4. Top 10 journals that have relevant articles on engineering design process topic

\begin{tabular}{|c|c|c|c|c|}
\hline No & Name of Journal & $\begin{array}{c}\text { Total } \\
\text { Articles }\end{array}$ & Cites & $\begin{array}{l}\text { Avg. } \\
\text { Cites }\end{array}$ \\
\hline 1 & Journal of Mechanical Design & 49 & 370 & 7.6 \\
\hline 2 & $\begin{array}{l}\text { International Journal of Technology and } \\
\text { Design Education }\end{array}$ & 42 & 436 & 10.4 \\
\hline 3 & $\begin{array}{l}\text { Journal of Pre-College Engineering } \\
\text { Education Research }\end{array}$ & 20 & 233 & 11.7 \\
\hline 4 & International Journal of STEM Education & 19 & 1668 & 87.8 \\
\hline 5 & $\begin{array}{l}\text { Journal of Science Education and } \\
\text { Technology }\end{array}$ & 16 & 441 & 27.6 \\
\hline 6 & Journal of Engineering Design & 14 & 119 & 8.5 \\
\hline 7 & $\begin{array}{l}\text { International Journal of } \\
\text { Science and Mathematics } \\
\text { Education }\end{array}$ & 12 & 307 & 25.6 \\
\hline 8 & $\begin{array}{l}\text { European Journal of Engineering } \\
\text { Education }\end{array}$ & 11 & 147 & 13.4 \\
\hline 9 & Journal of Engineering Education & 11 & 429 & 39.0 \\
\hline 10 & International Jounal of Science Education & 10 & 216 & 21.6 \\
\hline
\end{tabular}

The data network visualization display on GS data related to the engineering design process topic that has been selected is shown in Figure 2. Figure 3 shows the overlay visualization and Figure 4 shows the density visualization. 
International Journal of STEM Education for Sustainability, Vol 2, No.2, 2022, pp. 180-192

e-ISSN 2798-5091. DOI. 10.53889/ijses.v2i2.55

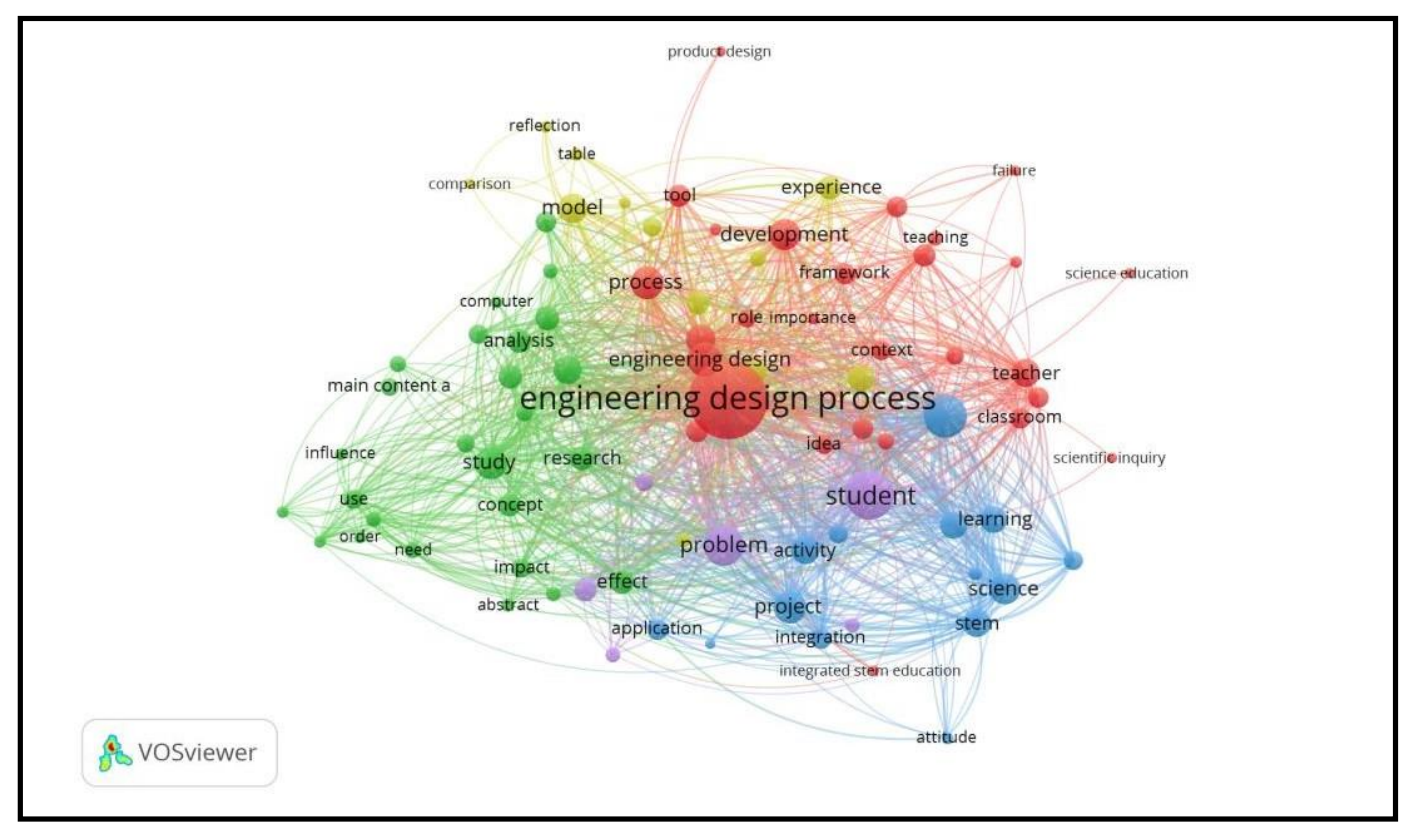

Figure 2. Network visualization on the GS database

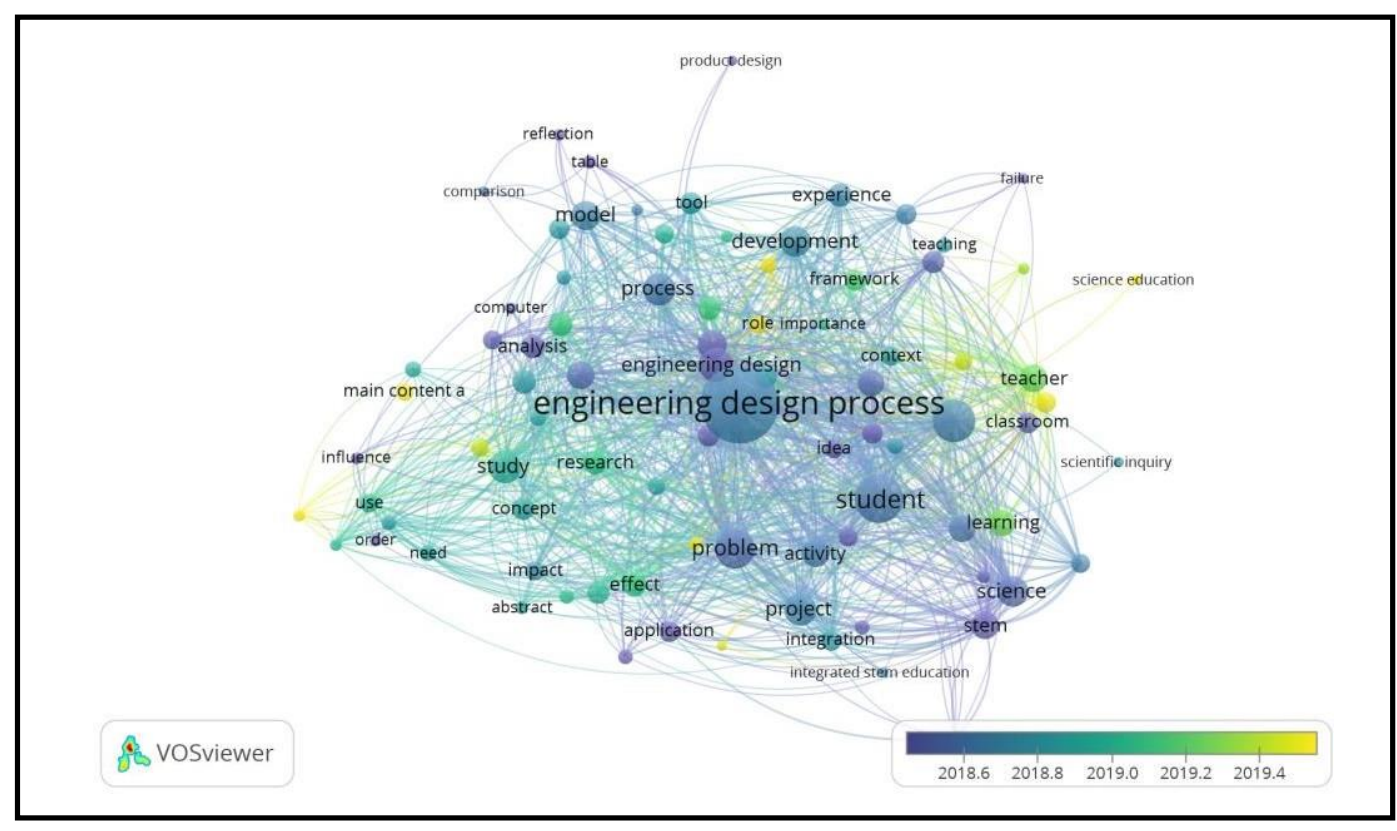

Figure 3. Visualization of overlays in the GS database 


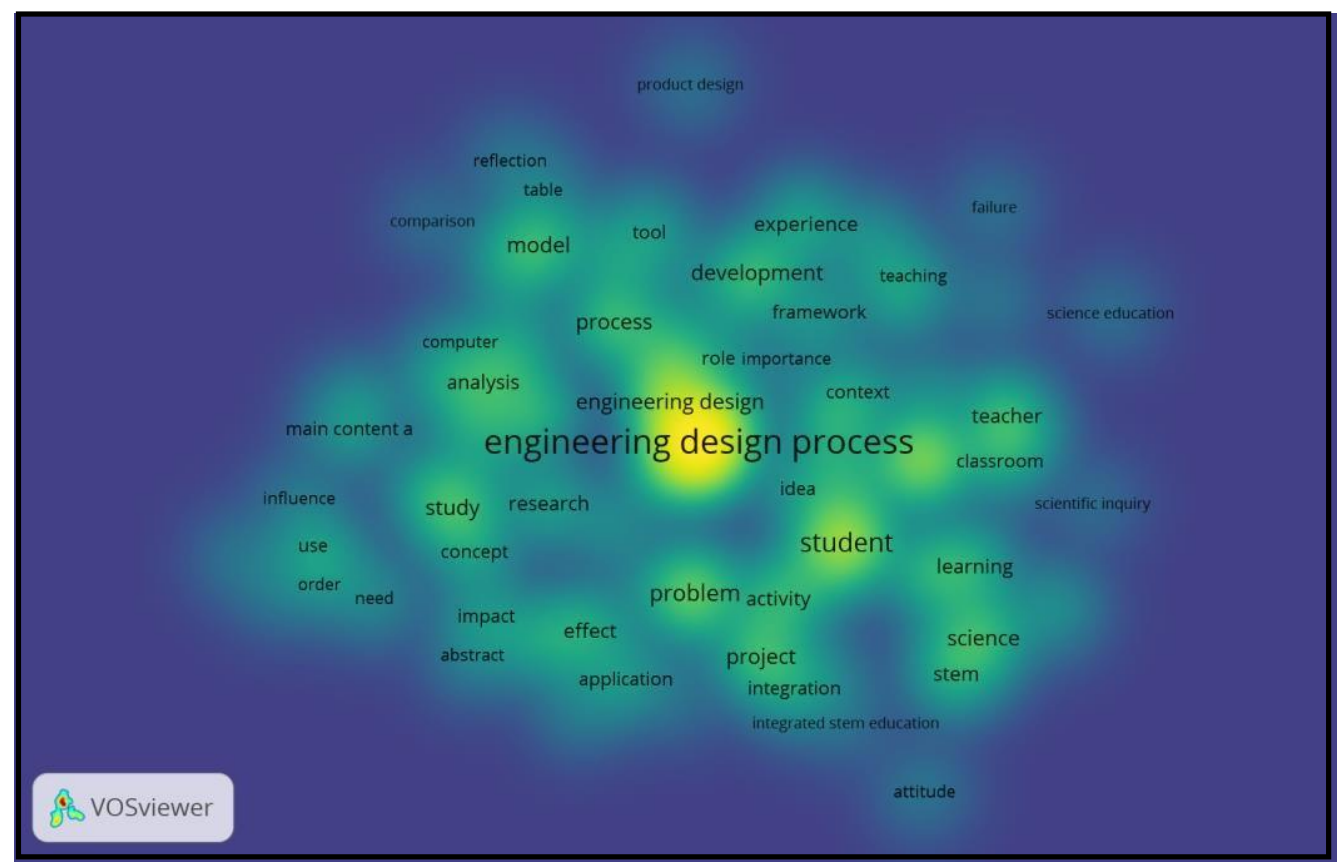

Figure 4. Visualization of density in the GS database

These results were extracted from the title, keywords, and abstract with a complete calculation of the minimum number of occurrences which was set to 10 . About 108 items were found that met the threshold of the 5095 items. Common words are not included in this item. Each item representing the keyword is added, which is indicated by the node size. That is, the node size here shows how often the keywords appear together. The results identified five groups of keywords. The keywords that appear in each of these clusters represent the flow of the engineering design process, which can be seen in Table 5.

Table 5. Keyword representing each cluster

\begin{tabular}{|c|c|c|}
\hline No & Cluster & lement \\
\hline 1 & The first cluster (red) & $\begin{array}{l}\text { additive manufacturing (14), analysis (56), chalenge (30), } \\
\text { concept (46), course (55), creativity (31), design thinking (20), } \\
\text { designer (27), education (76), effect }(56) \text {, environment }(25) \text {, } \\
\text { evalution (21), impact (36), influence (14), need (27), order } \\
\text { (16), outcome (21), participant (14), research (51), researcher } \\
\text { (13), study (103), use (37) }\end{array}$ \\
\hline 2 & $\begin{array}{l}\text { The second } \\
\text { cluster(green) }\end{array}$ & $\begin{array}{l}\text { ability (20), approach (87), computer (14), constraint (20), } \\
\text { design process (42), development (91), engineering design } \\
\text { process (605), idea (33), implementation (28), importance (15), } \\
\text { process (96), product (38), product design (12), solution (47), } \\
\text { system (51), teaching (20) }\end{array}$ \\
\hline 3 & $\begin{array}{l}\text { The third cluster } \\
\text { (blue) }\end{array}$ & $\begin{array}{l}\text { classroom (39), context (37), curriculum (43), edp (39), } \\
\text { engineer (39), engineering (176), engineering education (45), } \\
\text { engineering practice (15), failure (12), framework (41), } \\
\text { integrated stem education (10), role(30), science education } \\
\text { (11), scientific inquiry (10), stem education (31), teacher (78) }\end{array}$ \\
\hline 4 & $\begin{array}{l}\text { Fourth cluster } \\
\text { (yellow) }\end{array}$ & $\begin{array}{l}\text { child (27), comparison (10), engineering design (105), } \\
\text { engineering student (16), experience (57), knowledge (68), } \\
\text { model (83), practice (51), problem (146), reflection (13), skill } \\
\text { (46), stem activity (17), tool (45), understanding (36) }\end{array}$ \\
\hline
\end{tabular}




\begin{tabular}{lll}
\hline No & Cluster & Element \\
& & activity (77), application (44), attitude (15), case study (36), \\
& the fifth cluster & effectiveness (11), integration (42), learning (68), lesson (17), \\
(purple) & $\begin{array}{l}\text { mathematics (36), project (100), science (88), stem (72), } \\
\text { student (223), technology (69) }\end{array}$ \\
\hline
\end{tabular}

\section{Authors and co-authorship relations}

Figure 5 shows the results of the co-author and network analysis related to the pattern of collaboration between individuals. In this network, nodes represent each author connection in his writing. We can integrate many different dimensions into this analysis to visualize groupings and relationships between dimensions, or change over time. Figure 5 shows an analysis of the authors' network in terms of co-author years. In this case, the authors' relationship can be classified as their annual relationship. There are 6 authors connected to each other. It is evident that Strmel, g.j is the author with whom the others relate the most. Meanwhile, recent studies are marked in yellow, as was done by Purzer,s

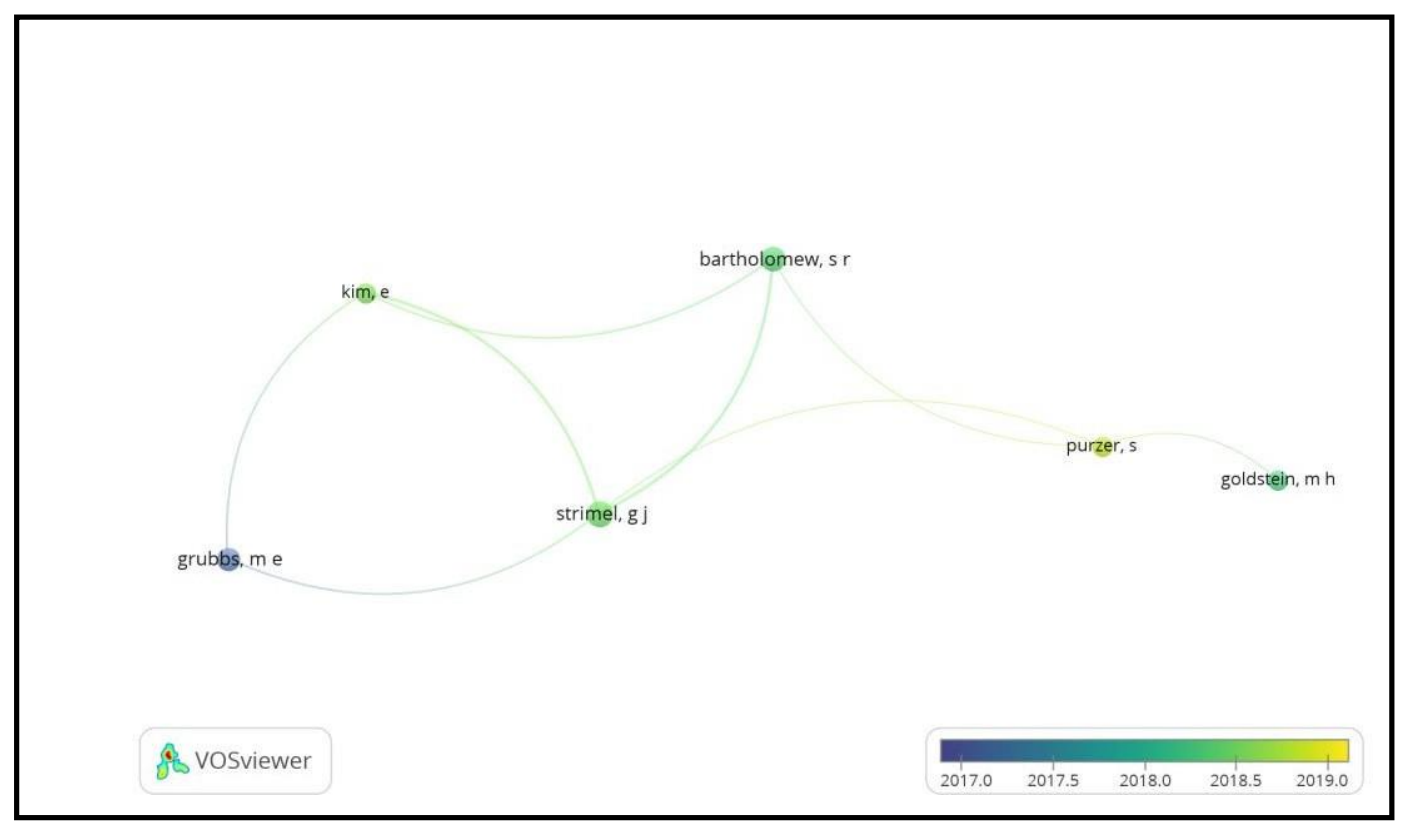

Figure 5. Visualization of overlay Authors and co-authorship relations on the GS database

The number of citations is the most relevant thing in contributing to this research. Based on Table 2, the higest citation indexed by GS is an article written by Todd R. Kelley \& J. Geoff Knowles in 2016. This article discusses the operationalization of key STEM education concepts and combines learning theories to build an integrated STEM education framework for helpful in researching more about integrated STEM education. This article has been cited in 966 research articles.

Besides that, in this study, it was also investigated which publishers contributed the most articles to the topic of "engineering design process". Of the 762 articles analyzed, the most published by Springer were 107 articles, followed by Taylor \& Francis 81 articles, 
asmedigitalcollection.asme.org 56 articles, ERIC 47 articles, Wiley Online Library 29 articles, researchgate.net 26 articles, Koreascience.or.kr 25 articles, docs.lib.purdue.edu 22 articles, Elsevier 20 articles and Journals.sagepub.com 17 articles.

In addition, the analysis was also carried out based on the relevance of the journal. The result is that in the top 10 journals covering this topic. The journal that publishes the most articles on the topic of engineering design process is Journal of Mechanical Design with 49 articles. But the journals that have the most avg.citations, namely International Journal of STEM Education. This means that articles on topics related to the engineering design process are distributed in certain journals, although there are also other journals.

\section{CONCLUSION}

Identification of the main themes in a research or knowledge discipline can use the analysis of overlay visualization and density visualization. Vosviewer software is used for analysis in this study. It can be seen that each cluster is associated with different keywords. This may indicate that the development of research on this topic is relevant.

In this study, journal articles with the keyword engineering design process were evaluated. Articles were retrieved from the GS database with the help of PoP software. A search with the keyword engineering design process resulted in 999 articles related to these keywords from 2016 to 2021. After the selection, 762 articles were obtained which were then analyzed. To achieve the purpose of this study, all articles were then grouped by author, year of publication, publisher's journal name, citation, and co-authors. This research gap can be used as a reference to study the importance of conducting further research on the design engineering process.

\section{SUGGESTIONS}

For further research, the use of a larger data sample by expanding the keywords used is highly recommended and also makes the database more accessible. In addition, it is also advisable to use a comparison of the results of different and recommended bibliometric analyzes (such as BibExcel and HistCite). And so that further related research can provide a more detailed explanation because there is still limited research that discusses the engineering design process.

\section{REFERENCES}

Ahmi, A., Elbardan, H., \& Ali, R. H. R. M. (2019, January). Bibliometric analysis of published literature on industry 4.0. In 2019 International Conference on Electronics, Information, and Communication (ICEIC) (pp. 1-6). IEEE.

Arık, M., \& Topçu, M. S. (2020). Implementation of engineering design process in the K12 science classrooms: Trends and issues. Research in Science Education, 1-23. 
Baneyx, A. (2008). "Publish or Perish" as citation metrics used to analyze scientific output in the humanities: International case studies in economics, geography, social sciences, philosophy, and history. Archivum immunologiae et therapiae experimentalis, 56(6), 363-371.

Carr, R. L., Bennett IV, L. D., \& Strobel, J. (2012). Engineering in the K-12 STEM standards of the 50 US states: An analysis of presence and extent. Journal of Engineering Education, 101(3), 539-564.

Hafiz, N. R. M., \& Ayop, S. K. (2019). Engineering Design Process in Stem Education: A Systematic. International Journal of Academic Research in Business and Social Sciences, 9(5).

Haik, Y., Sivaloganathan, S., \& Shahin, T. M. (2010). Engineering design process. Cengage Learning.

Han, H. J., \& Shim, K. C. (2019). Development of an engineering design process-based teaching and learning model for scientifically gifted students at the Science Education Institute for the Gifted in South Korea. Asia-Pacific Science Education, 5(1), 1-18.

Hudha, M. N., Hamidah, I., Permanasari, A., Abdullah, A. G., Rachman, I., \& Matsumoto, T. (2020). Low Carbon Education: A Review and Bibliometric Analysis. European Journal of Educational Research, 9(1), 319-329.

Kelley, T. R., \& Knowles, J. G. (2016). A conceptual framework for integrated STEM education. International Journal of STEM education, 3(1), 1-11.

Li, Z., Lu, J., Wang, G., Feng, L., Broo, D. G., \& Kiritsis, D. A Bibliometric Analysis on Model-based Systems Engineering. In 2021 IEEE International Symposium on Systems Engineering (ISSE) (pp. 1-8). IEEE.

Long, N. T., Yen, N. T. H., \& Van Hanh, N. (2020). The Role of Experiential Learning and Engineering Design Process in K-12 Stem Education. International Journal of Education and Practice, 8(4), 720-732.

National Research Council. (2009). Final report from the NRC Committee on the Review of the Louisiana Coastal Protection and Restoration (LACPR) Program. National Academies Press.

Sürmeli, H., Yıldırım, M., GÖCÜK, A., \& SEVGİ, Y. (2018). secondary school students' performance and opinions towards activities based on engineering design process. Cukurova University Faculty of Education Journal, 47(2), 844-872.

Winarno, N., Rusdiana, D., Samsudin, A., Susilowati, E., Ahmad, N. J., \& AFIFAH, R. M. A. (2020). The steps of the Engineering Design Process (EDP) in science education: A systematic literature review. Journal for the Education of Gifted Young Scientists, 8(4), 1345-1360.

Yildiz, S., G., \& Ozdemir, A. S. (2020). The effects of engineering design processes on spatial abilities of middle school students. International Journal of Technology and Design Education, 30(1), 127-148. 
International Journal of STEM Education for Sustainability, Vol 2, No.2, 2022, pp. 180-192 e-ISSN 2798-5091. DOI. 10.53889/ijses.v2i2.55

Zheng, H., Liu, W., \& Xiao, C. (2018). Structural relationship model for design defect and influencing factors in the concurrent design process. International Journal of Production Research, 56(14), 4897-4924. 